\title{
OSPREY WITH MUSKRAT
}

By PATRICIA R. KERN, 1053 Chestnut Ave., Moose Jaw, Sask., S6H 1 A7

On October 19, 1975, a sunny, warm fall day, I drove down a short side road from the highway to look at the swans and ducks. At the marshy west end of Crooked Lake in the Qu'Appelle Valley about 150 feet north along the shore on a mud bar, an Osprey was standing, biting at something. Probably because its feathers were ruffled, the bird seemed very large; its breast was darkly spotted and back feathers were edged in white. Several times the bird flew up a few feet and then pummelled down onto its prey with its talons. Disturbed by my car and others passing on the main road, the Osprey moved over to another mud bar several hundred yards away. When it flew, the limp form of a muskrat was held by the talons of one foot. The hawk then proceeded to feed on the animal, later moving further into the marsh to a muskrat house where it continued feeding for another 10 to 15 minutes before leaving the area.

I have seen Ospreys twice at Buffalo Lake north of Moose Jaw: one made a steep dive into the water for a fish, and another rested in a tree by the lake. I have also seen them at Round and Crooked Lakes in the Qu'Appelle Valley. They seem to be scarce migrants along the chain of lakes.

About $95-98 \%$ of the Osprey's food consists of fish, hence its common name of "fish hawk". It takes mostly non-game fish such as catfish, suckers, carp, etc., but also perch, trout and many others, occasionally even raiding fish hatcheries. Rarely have they been noted taking frogs, water snakes, birds, small ducks, chickens and small mammals, but muskrats are not listed.

A. C. Bent states that, if Ospreys take other kinds of food besides fish, it must be on rare occasions.' Sprunt states that any variation from a fish

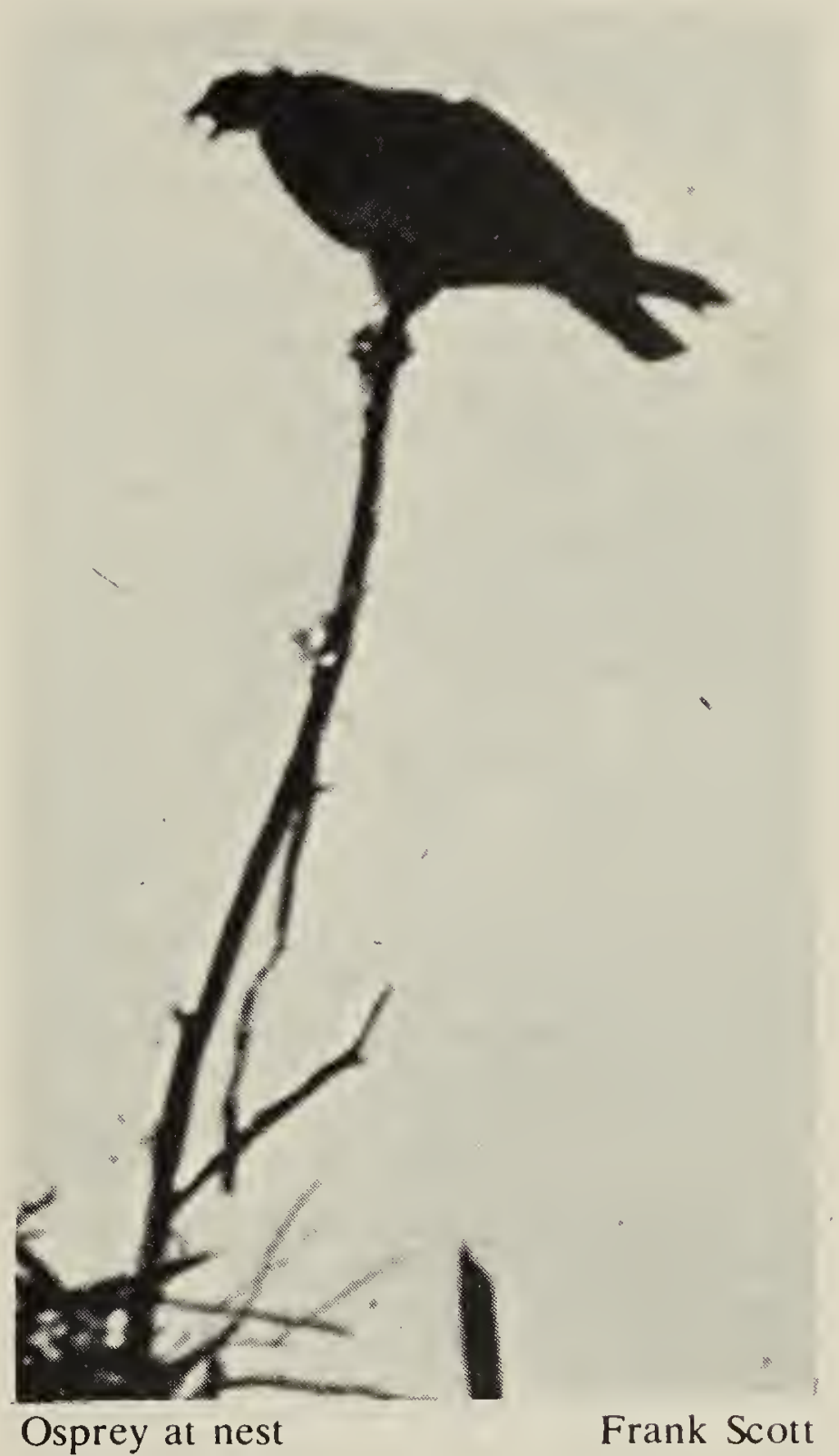

"diet is out of the ordinary and can fairly be considered an abnormality."3 Other authors say that if anything but fish is taken, it is probably because of extreme hunger; however, Grossman and Hamlet report Ospreys have been known to take other prey as mentioned above. $^{2}$

'BENT, A. C. 1961. Life Histories of North American birds of prey. Part l. Dover, N.Y. 409 p.

"GROSSMAN, M. L., and JOHN HAMLET. 1964. Birds of prey of the uorld. Clarkson N. Potter, New York. 496 p.

:SPRUNT, A., Jr. 1955. North American hirds of prey. Harper \& Brothers. New York. 227 p. 